\title{
Analisis Peningkatan Tahanan Geser Tanah Lunak akibat adanya Cerucuk berdasarkan Permodelan di Laboratorium
}

\author{
Isti Qomariyah, Indrasurya B Mochtar, dan Yudhi Lastiasih \\ Jurusan Teknik Sipil, Fakultas Teknik Sipil dan Perencanaan, Institut Teknologi Sepuluh Nopember \\ Jl. Arief Rahman Hakim, Surabaya 60111 Indonesia \\ e-mail: indramochtar.mochtar@gmail.com, yudhi.lasatiasih@gmail.com
}

\begin{abstract}
Abstrak - Berbagai metode telah dikembangkan dalam analisa perkuatan talud yang menggunakan cerucuk. Salah satunya adalah Teori Cerucuk oleh Mochtar (2000). Teori ini didasarkan pada Manual Design NAVFAC DM-7 [3]. Kemudian dilakukan pembaharuan rumus oleh Mochtar \& Arya [2] yang didasarkan pada pemodelan di laboratorium. Dan pembaruan rumus yang terbaru oleh Rusdiansyah (2015) yang memperoleh faktor koreksi gabungan terhadap rumus Mochtar (2000) yakni koreksi terhadap panjang tancap, spasi pemasangan, diameter, serta jumlah dan efisiensi. Namun teori cerucuk oleh Rusdiansyah (2015) [4] masih memiliki batas perhitungan. Sehingga perlu diadakan penelitian lanjut untuk memperluas batas tersebut.

Penelitian ini dilakukan dengan cara sampling tanah lalu sampel tersebut di uji geser di Laboratorium untuk mengetahui gaya maksimum yang bisa ditahan oleh tanah maupun tanah yang ditancapi cerucuk mini. Gaya inilah yang diolah menjadi persamaan pengaruh variasi cerucuk. Hasil perhitungan perumusan menghasilkan persamaan tambahan pada Rumus Cerucuk 2015. Pada variasi rasio tancap cerucuk diperoleh persamaan $Y t=0.001(X t)^{2}+0.051(X t)-0.180$. Pada variasi spasi pemasangan didapat persamaan untuk rasio spasi terhadap diameter $(\mathrm{S} / \mathrm{D})$ lebih dari $5, \mathrm{Ys}_{\mathrm{s}=-0.027}(\mathrm{Xs})+1.138$. pada variasi jumlah cerucuk didapat persamaan baru yakni $\mathrm{Yn}=0.0055(\mathrm{Xn})^{2}$ - 0.0892(Xn) + 1.1001. Sedangkan untuk variasi diameter diperoleh persamaan $\mathrm{Yd}=1.337(\mathrm{Xd})+0.869$ untuk rasio diameter terhadap kekakuan (D/T) kurang dari 0.098. Dengan rata-rata koefisien pengali adalah 2.095 .
\end{abstract}

Kata Kunci-Cerucuk, Direct Shear, Permodelan, Tahanan Geser.

\section{PENDAHULUAN}

\section{A. Latar Belakang}

CERUCUK merupakan suatu metode perbaikan tanah yang sering dijumpai guna meningkatkan daya dukung pada tanah yang lunak maupun sebagai penguat lereng timbunan. Cerucuk bisa berupa tiang kayu berukuran panjang 4-6 meter dengan diameter $10 \mathrm{~cm}$. Bisa juga tiang beton untuk tanah lunak yang lebih dalam, dan bila kapasitas daya dukung beban yang lebih besar diperlukan, penggunaan dari tiang beton pracetak lebih cocok. Tiang pracetak bebentuk persegi atau segitiga dengan sisi berukuran 10-40 cm, akan memberikan kapasitas daya dukung yang lebih besar (Departemen PU, 2005).

Cerucuk telah berhasil digunakan di berbagai situasi penanganan kelongsoran maupun peningkatan stabilitas talud, dan banyak metode yang telah dikembangkan dalam analisis pile slopes atau cerucuk (Ito et al.,1981; Poulos, 1995; chen and Poulos, 1997; Zeng and Liang, 2002; Won et al., 2005) [1]. Teori cerucuk terbaru adalah Teori Cerucuk 2015 yang diperkenalkan oleh Rusdiansyah [4]. Teori ini dikembangkan dari teori cerucuk Mochtar (2000) yang mengasumsikan kelompok cerucuk dianggap sebagai kelompok tiang pancang "rigid cap" di muka tanah yang menerima gaya horizontal. Gaya horizontal tersebut merupakan tegangan geser yang terjadi disepanjang bidang gelincir seperti yang ditunjukkan oleh Gambar 1.1. Asumsi tersebut didasarkan pada teori tiang pancang penahan horizontal oleh NAVFAC DM-7,1971 [3].

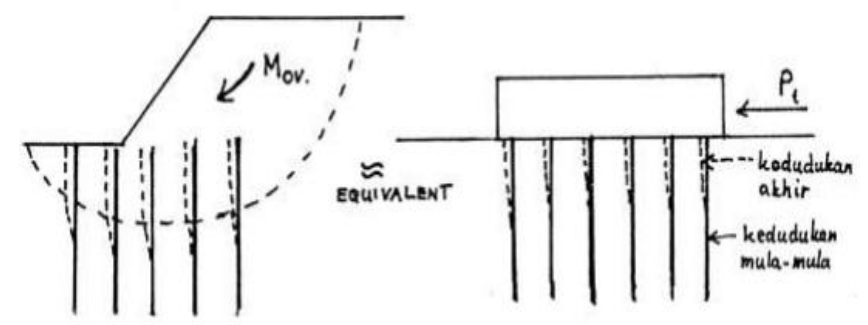

Gambar 1. Asumsi Gaya yang Diterima Cerucuk (Mochtar,2000)

Namun Teori Cerucuk 2015 masih terbatas oleh persyaratan benda uji : 1) Spasi 3D (3 kali diameter) sampai 8D (8 kali diameter), 2) Rasio tancap $\mathrm{L} / \mathrm{D}=5$ s.d. $\mathrm{L} / \mathrm{D}=20,3$ ) Rasio $\mathrm{D} / \mathrm{T}$ yang digunakan 0.099 s.d. 0.113,4) Diameter Cerucuk $3 \mathrm{~mm}$ s.d. $6 \mathrm{~mm}$. Oleh sebab itu, diusulkan penelitian lanjut mengenai "Analisis Peningkatan Tahanan Geser Tanah Lunak akibat adanya Cerucuk berdasarkan Permodelan di Laboratorium" untuk melengkapi persyaratan-persyaratan pada Teori Cerucuk 2015 .

\section{B. Rumusan Masalah}

1. Bagaimana kekuatan geser tanah maximum tanpa adanya cerucuk?

2. Bagaimana pengaruh pemasangan Cerucuk spasi $>8 \mathrm{D}$ terhadap kuat geser tanah?

3. Bagaimana pengaruh pemasangan Cerucuk rasio tancap L/D $>20$ terhadap kuat geser tanah?

4. Bagaimana pengaruh pemasangan Cerucuk diameter $2 \mathrm{~mm}$ dan 2,5 mm terhadap kuat geser tanah?

5. Bagaimana pengaruh pola pemasangan Cerucuk terhadap kuat geser tanah? 


\section{Batasan Masalah}

1. Jenis tanah yang digunakan dalam penelitian adalah tanah lunak atau tanah kohesif.

2. Dasar perumusan Cerucuk mengacu pada NAVFAC DM-7 teori tiang pancang penahan horizontal.

3. Kekuatan geser tanah kohesif ditentukan dengan alat uji geser langsung (direct shear) yang telah dimodifikasi.

\section{Tujuan}

Tujuan penulisan Tugas Akhir ini adalah untuk melengkapi persyaratan perumusan Teori Cerucuk 2015

\section{E. Manfaat}

Manfaat dari penulisan laporan tugas akhir ini adalah untuk merumuskan perhitungan Cerucuk yang lebih mendekati kejadian sebenarnya dilapangan sesuai dengan keberagaman kondisi di lapangan.

\section{METODOLOGI}

Adapun metode penelitian yang digunakan dalam penelitian ini adalah sebagai berikut:

\section{1) Studi Literatur.}

Pengumpulan bebagai literature mengenai permodelan laboratotium tentang peningkatan tahanan geser tanah dan analisisnya.

\section{2) Pembuatan sampel benda uji.}

Benda uji ceucuk yang akan diuji berukuran mini yakni diameter $2 \mathrm{~mm}$ dan $2,5 \mathrm{~mm}$ serta panjang sekitar $20 \mathrm{~cm}$ dengan bahan dasar bambu. Benda uji tanah berbentuk kotak dengan dimensi $20 \mathrm{~cm} \times 15 \mathrm{~cm} \times 18 \mathrm{~cm}$ dan $20 \mathrm{~cm} \times 15 \mathrm{~cm} \times 12 \mathrm{~cm}$. Pengambilan sampel tanah dilakukan menggunakan kotak sampel yang terbuat dari besi

\section{3) Pengujian karakteristik benda uji.}

Pengujian karakteristik cerucuk menggunakan uji lentur untuk memperoleh modulus elastisitas (E) dan tegangan lentur bahan. Sedangkan pada pengujian karakteristik tanah, dilakukan uji sifat fisik, uji plastisitas, serta pengujian geser.

\section{4) Pengujian tahanan geser tanah dengan berbagai variabel.}

Pengujian tahanan geser tanah-cerucuk untuk memperoleh besar gaya geser yang dapat ditahan oleh model tanah-cerucuk (Plab) dengan beberapa variasi perlakuan, yaitu spasi pemasangan, diameter cerucuk, rasio tancap, jumlah cerucuk serta pola pasang.

\section{5) Analisis hasil.}

Semua pengujian terhadap benda uji dengan variasi perlakuan yang akan dilakukan menghasilkan besar gaya geser yang dapat ditahan oleh benda uji tersebut (Plab). Plab untuk masing-masing variasi perlakuan dari hasil percobaan laboratorium akan dibandingkan dengan Panalitis. Dimana Panalitis adalah gaya geser yang ditentukan secara analitis dengan menggunakan rumus NAVFAC DM.7. Perbandingan ini akan menghasilkan nilai koreksi. Selain itu hubungan Plab untuk masing-masing variasi perlakuan akan menjadi pemodelan empiris untuk kekuatan geser cerucuk dalam tanah dengan faktor-faktor koreksi

\section{HASIL PENGUJIAN}

\section{A. Benda Uji}

Benda Uji Cerucuk

Sampel cerucuk berbahan dasar bambu. Untuk menjaga sifat homogen bahan maka bambu yang digunakan harus dari satu batang yang sama, bagian yang digunakan adalah bagian tengah, bukan pada bagian tepi kulit bambu, serta ruas bambu tidak boleh disertakan.

Hasil dari pengujian lentur adalah grafik hubungan antara gaya dan lendutan yang terjadi seperti ditunjukkan pada Gambar 1. Dari nilai gaya dan lendutan dapat diperoleh nilai modulus elastisitas rata-rata dari setiap spesimen dengan menggunakan metode luasan momen seperti ditunjukkan oleh Tabel 1 Hasil menunjukkan nilai koefisien varisi tergolong kecil (11\%) kurang dari 20\%. Hal ini mengindikasikan bahwa bahan cerucuk yang digunakan relatif homogen.

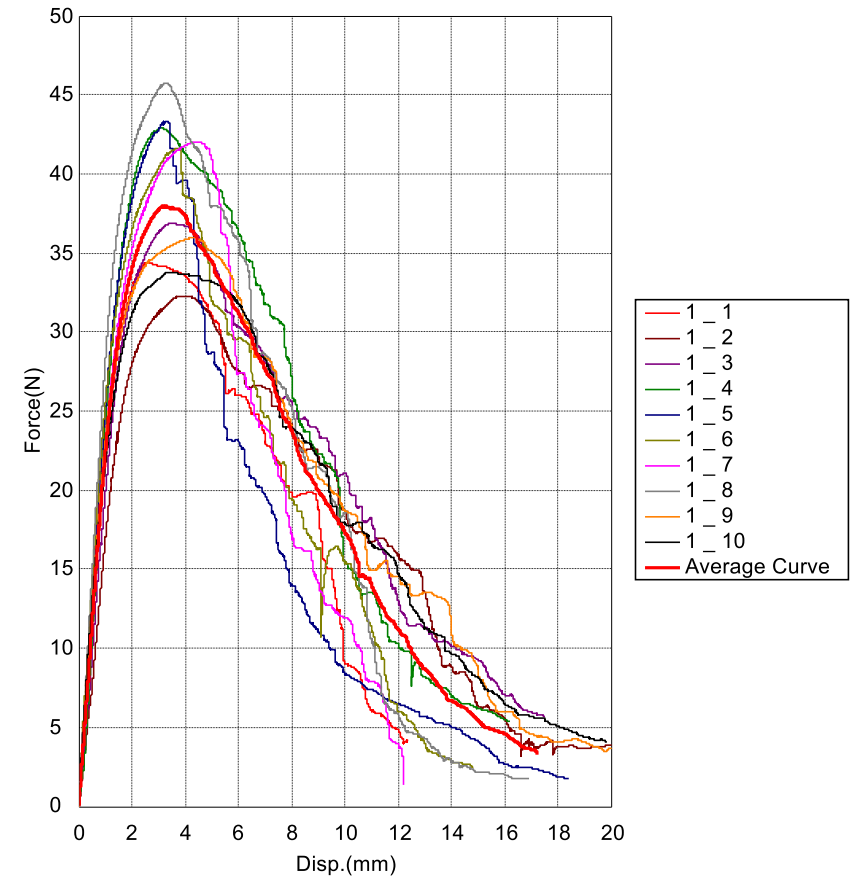

Gambar 2. Grafik Hasil uji lentur specimen 1-1

Tabel 1.

Nilai E rata-rata

\begin{tabular}{|c|c|c|c|c|c|c|c|c|c|c|c|}
\hline & & $1 \_1$ & $1 \_2$ & $1 \_3$ & $1 \_4$ & $1 \_5$ & $1 \_6$ & $1 \_7$ & $1 \_8$ & $1 \_9$ & $1 \_10$ \\
\hline$P 1$ & $\mathrm{~N}$ & 10.01596 & 6.516775 & 8.178552 & 9.262562 & 10.85122 & 12.29922 & 10.23928 & 13.0256 & 11.127 & 11.60701 \\
\hline$P 2$ & $\mathrm{~N}$ & 25.00852 & 19.63774 & 22.97878 & 27.57152 & 28.48228 & 28.2383 & 25.85093 & 31.91153 & 25.56165 & 23.99047 \\
\hline$\Delta 1$ & $\mathrm{~mm}$ & 0.4515 & 0.4515 & 0.4515 & 0.4515 & 0.4515 & 0.451475 & 0.4515 & 0.4515 & 0.4515 & 0.4515 \\
\hline$\Delta 2$ & $\mathrm{~mm}$ & 1.1765 & 1.176475 & 1.176475 & 1.176475 & 1.1765 & 1.176475 & 1.1765 & 1.176475 & 1.1765 & 1.1765 \\
\hline$\varepsilon 1$ & & 0.01806 & 0.01806 & 0.01806 & 0.01806 & 0.01806 & 0.018059 & 0.01806 & 0.01806 & 0.01806 & 0.01806 \\
\hline$\varepsilon 2$ & & 0.04706 & 0.047059 & 0.047059 & 0.047059 & 0.04706 & 0.047059 & 0.04706 & 0.047059 & 0.04706 & 0.04706 \\
\hline $\mathrm{I}$ & $\mathrm{mm} 4$ & 1.917476 & 1.917476 & 1.917476 & 1.917476 & 1.917476 & 1.917476 & 1.917476 & 1.917476 & 1.917476 & 1.917476 \\
\hline $\mathrm{L}$ & $\mathrm{mm}$ & 50 & 50 & 50 & 50 & 50 & 50 & 50 & 50 & 50 & 50 \\
\hline $\mathrm{E}$ & $\mathrm{N} / \mathrm{mm} 2$ & 280855.14 & 24579.98 & 27725.81 & 34298.84 & 33027.77 & 29858.23 & 29244.87 & 35379.7 & 27040.03 & 23197.59 \\
\hline EAVG & $\mathrm{N} / \mathrm{mm} 2$ & 29243.8 & & & & & & & & & \\
\hline STDEV & & 3291.629 & & & & & & & & & \\
\hline STDEV/AVG & & $11 \%$ & & & & & & & & & \\
\hline
\end{tabular}




\section{Benda Uji Tanah}

Kegiatan sampling tanah berlokasi di belakang Gedung Robotika ITS. Pengambilan benda uji tanah dilakukan dengan cara pengupasan pada permukaan tanah sampai dengan elevasi dibawah muka air tanah. Pada benda uji tanah dilakukan uji karakteristik untuk mengetahui parameter yakni uji sifat fisik, uji plastisitas, dan uji geser. Dari pengujian karakteristik tanah diketahui bahwa tanah tergolong jenis lempung dengan berat volume $1,354 \mathrm{gr} / \mathrm{cc}$ dan kadar air $100 \%$ seperti yang ditunjukkan oleh Tabel 2.

Tabel 2.

Sifat fisik dan mekanis tanah kondisi undisturbed

\begin{tabular}{|l|c|c|}
\hline Lokasi & & Gedung Robotika ITS \\
\hline Kedalaman Sampel & & $-1,00 \mathrm{~m}$ \\
\hline Kedalaman MAT & & $0.00 \mathrm{~m}$ \\
\hline Kondisi Cuaca & & Nujan Sedang - Hujan Lebat \\
\hline Waktu & & 1.345 \\
\hline Berat/volume tanah Yt & gr/cc & 0.668 \\
\hline Berat/volume kering Yd & gr/cc & 1.014 \\
\hline Kadar air & $\%$ & 0.942 \\
\hline Derajad Kejenuhan Sr & gr & 0.732 \\
\hline Kadar Pori & $\%$ & 2.766 \\
\hline Angka Pori $\quad$ Gs & & 2.524 \\
\hline Spesifik Gravity $\quad$ PL & $\%$ & 91.535 \\
\hline Batas cair & $\%$ & 45.67627494 \\
\hline Batas Plastis & $\%$ & 45.859 \\
\hline Indeks Plastisitas PI & $\%$ & 73.59 \\
\hline Fraksi Lempung & $\%$ & 20.42 \\
\hline Fraksi Lanau & & 5.99 \\
\hline Fraksi Pasir & & A-7 (Tanah Berlempung) \\
\hline Klasifikasi USCS & & \\
\hline Klasifikasi AASHTO & & CH \\
\hline
\end{tabular}

\section{B. Pengujian Tahanan Geser Tanah}

Setelah proses pengambilan tanah, dilakukan uji geser tanah maupun tanah-cerucuk dengan menggunakan alat Direct Shear yang telah dimodifikasi seperti yang ditampilkan pada Gambar 3.2. Prosedur pengujian geser mengacu pada hasil penelitian Rusdiansyah (2015). Variasi perlakuan pada benda uji tanah cerucuk adalah spasi (10 kali diameter, 15 kali diameter), diameter (2 $\mathrm{mm}$ dan $2.5 \mathrm{~mm}$ ), rasio panjang tancap $(22,24,28)$, jumlah pemasangan $(1 \times 2,1 \times 3,1 \times 5)$, dan pola pemasangan $(2 \times 3,3 \times 2)$

Pengujian geser tidak hanya menghasilkan nilai gaya maksimum yang mampu ditahan (P max), namun juga nilai Cohesi Undrained atau $\mathrm{Cu}$. Dengan menganggap sudut geser $(\theta)$ sama dengan nol, maka nilai tegangan geser $(\tau)$ yang terjadi sama dengan nilai $\mathrm{Cu}$. Hasil dari pengujian geser tanpa cerucuk dapat dilihat pada Tabel 3.3 dan Tabel 3.4 untuk pengujian dengan bebagai variasi perlakuan.

Nilai Pmax pada sampel tanah-cerucuk masih merepresentasikan besarnya gaya yang mampu ditahan oleh cerucuk dan tanah itu sendiri. Untuk mengetahui kemampuan 1 batang cerucuk dalam menerima gaya geser, nilai Pmax sampel tanah-cerucuk dikurangi dengan Pmax sampel tanah tanpa cerucuk kemudian dibagi dengan jumlah cerucuk yang ditancap. Nilai ini disebut $\Delta \mathrm{P} 1$ cerucuk. Perhitungan $\Delta \mathrm{P} 1$ cerucuk, dapat dilihat pada Tabel 3.5.

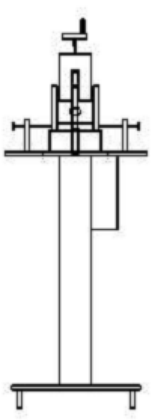

(a)

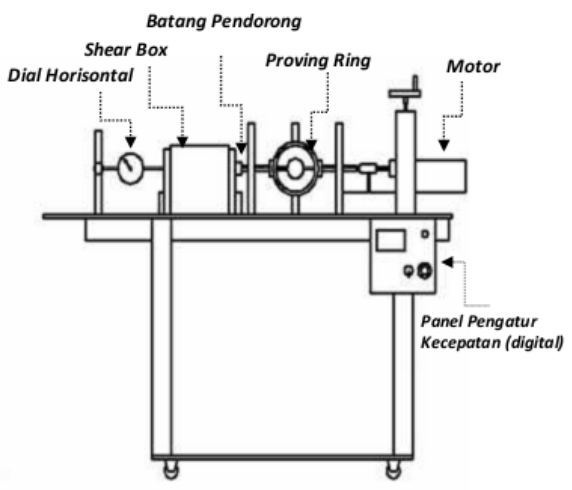

(b)

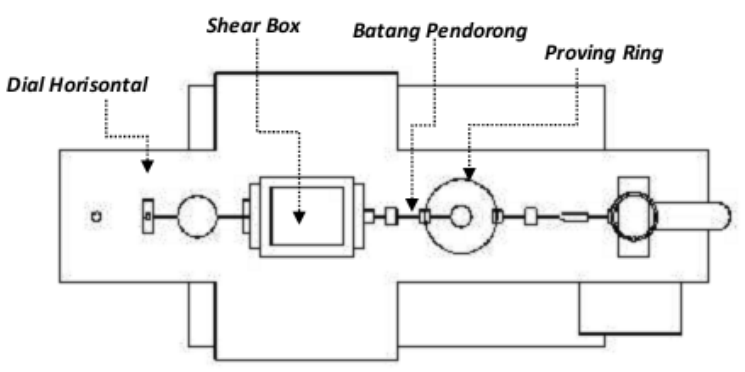

(c)

Gambar 3. Alat uji Geser Modofikasi (Rusdiansyah,2015) [4]

Tabel 3.

Pmax dan $\tau$ yang terjadi pada sampel variasi tanah-cerucuk

\begin{tabular}{|c|c|c|c|c|c|}
\hline \multirow{2}{*}{ No } & \multirow{2}{*}{ Sampel } & Load Ring Dial Reading & Pmax & $\tau$ & $\mathrm{Cu}$ \\
\cline { 3 - 6 } & $\mathrm{i}$ & div & $\mathrm{kgf}$ & $\mathrm{kg} / \mathrm{cm} 2$ & $\mathrm{~kg} / \mathrm{cm} 2$ \\
\hline 1 & $\mathrm{ii}$ & 9.2 & 21.914 & 0.0753 & 0.0753021 \\
\hline 2 & iii & 6.5 & 15.539 & 0.0540 & 0.0539545 \\
\hline 3 & iv & 6.9 & 16.495 & 0.0573 & 0.0572748 \\
\hline 4 & 6.9 & 16.495 & 0.0567 & 0.0566843 \\
\hline
\end{tabular}

Tabel 4.

Pmax dan $\tau$ yang terjadi pada sampel variasi tanah-cerucuk

\begin{tabular}{|c|c|c|c|c|c|}
\hline \multirow{2}{*}{ № } & \multirow{2}{*}{ Sampel } & Load Ring Dial Reading & Pmax & $\mathrm{T}$ & Cu cerucuk \\
\hline & & div & $\mathrm{kg}$ & $\mathrm{kg} / \mathrm{cm} 2$ & $\mathrm{~kg} / \mathrm{cm} 2$ \\
\hline 1 & 1×3.2,5.10D.22 (Spasi 10D I) & 9.5 & 22.711 & 0.0797 & 0.079686667 \\
\hline 2 & 1×3.2,5.10D.22 (Spasi 10D III) & 9 & 21.515 & 0.0755 & 0.07549 \\
\hline 3 & $1 \times 3.2,5.15 \mathrm{D} .22$ (Spasi 15D) & 9.0 & 21.5 & 0.0763 & 0.07630 \\
\hline 4 & 1×3.2.18D.27 (D2mm I) & 9 & 21.515 & 0.0747 & 0.07471 \\
\hline 5 & 1×3.2.18D.27 (D2mm II) & 9 & 21.515 & 0.0747 & 0.07471 \\
\hline 6 & 1×3.2.18D.27 (D2mm III) & 9 & 21.515 & 0.0755 & 0.07549 \\
\hline 7 & $1 \times 3.2,5.15 \mathrm{D} .22(\mathrm{D} 2,5 \mathrm{~mm})$ & 9.5 & 22.711 & 0.0763 & 0.07630 \\
\hline 8 & $1 \times 3.2,5.10 D .22(L / D=22)$ & 9.5 & 22.711 & 0.0797 & 0.07969 \\
\hline 9 & $1 \times 3.2,5.10 \mathrm{D} .24(\mathrm{LID}=24 \mathrm{I})$ & 10.2 & 24.384 & 0.0856 & 0.08556 \\
\hline 10 & $1 \times 3.2,5.10 \mathrm{D} .24$ (L/D = 24 III) & 9.2 & 21.994 & 0.0764 & 0.07637 \\
\hline 11 & $1 \times 3.2,5.10 D .28(L / D=28)$ & 11 & 26.297 & 0.0913 & 0.09131 \\
\hline 12 & 1x2.2,5.10D.22 (Jumlah 1×2) & 9 & 21.515 & 0.0763 & 0.07630 \\
\hline 13 & 1×3.2,5.10D.22 (Jumlah 1×3) & 9 & 21.515 & 0.0754926 & 0.07549 \\
\hline 14 & 1×5.2,5.10D.22 (Jumlah 1×5 I) & 11.2 & 26.775 & 0.0939 & 0.09395 \\
\hline 15 & 1×5.2,5.10D.22 (Jumlah 1×5 II) & 8 & 19.125 & 0.0693 & 0.06929 \\
\hline 16 & 1×5.2,5.10D.22 (Jumlah 1×5 III) & 10.9 & 26.058 & 0.0914 & 0.09143 \\
\hline 17 & $2 \times 3.2,5.100 .22$ (Pola 2×3) & 9.1 & 21.754 & 0.0771 & 0.07714 \\
\hline 18 & 3x2.2,5.10D.22 (Pola 3×2) & 7.7 & 18.408 & 0.0682 & 0.06818 \\
\hline
\end{tabular}


Tabel 5.

$\Delta \mathrm{P} 1$ cerucuk

\begin{tabular}{|c|c|c|c|c|c|c|}
\hline \multirow{2}{*}{ № } & \multirow{2}{*}{ Sampel } & $P \max$ & Pmax tanpa cerucuk & $\Delta \mathrm{P}$ & \multirow{2}{*}{ Jumlah cerucuk } & \multirow{2}{*}{\begin{tabular}{|c|}
$\Delta P 1$ cerucuk \\
$\mathrm{kg}$ \\
\end{tabular}} \\
\hline & & $\mathrm{kg}$ & $\mathrm{kg}$ & $\mathrm{kg}$ & & \\
\hline 1 & 1×3.2,5.10D.22 (Spasi 10D I) & 22.711 & 21.914 & 0.797 & 3 & 0.266 \\
\hline 2 & 1x3.2,5.10D.22 (Spasi 10D III) & 21.515 & 15.539 & 5.977 & 3 & 1.992 \\
\hline 3 & 1×3.2,5.15D.22 (Spasi 15D) & 21.5 & 16.495 & 5.020 & 3 & 1.673 \\
\hline 4 & 1 1×3.2.18D.27 (D2mm I) & 21.515 & 15.539 & 5.977 & 3 & 1.992 \\
\hline 5 & 1 1 33.2.18D.27 (D2mm II) & 21.515 & 15.539 & 5.977 & 3 & 1.992 \\
\hline 6 & 1×3.2.18D.27 (D2mm III) & 21.515 & 15.539 & 5.977 & 3 & 1.992 \\
\hline 7 & $1 \times 3.2,5.15 \mathrm{D} .22(\mathrm{D} 2,5 \mathrm{~mm})$ & 22.711 & 16.495 & 6.216 & 3 & 2.072 \\
\hline 8 & $1 \times 3.2,5.100 .22(L / D=22)$ & 22.711 & 21.914 & 0.797 & 3 & 0.266 \\
\hline 9 & 1x3.2,5.10D.24 (LID = 24I) & 24.384 & 16.495 & 7.889 & 3 & 2.630 \\
\hline 10 & $1 \times 3.2,5.10 D .24(\mathrm{LID}=24 \mathrm{III})$ & 21.994 & 16.495 & 5.498 & 3 & 1.833 \\
\hline 11 & $1 \times 3.2,5.10 D .28(L / D=28)$ & 26.297 & 16.495 & 9.801 & 3 & 3.267 \\
\hline 12 & 1x2.25.10D.22 (Jumlah 1x2) & 21.515 & 16.495 & 5.020 & 2 & 2.510 \\
\hline 13 & 1×3.2,5.10D.22 (Jumlah 1×3) & 21.515 & 15.539 & 5.977 & 3 & 1.992 \\
\hline 14 & 1 1x5.2,5.10D.22 (Jumlah 1×5 I) & 26.775 & 16.495 & 10.280 & 5 & 2.056 \\
\hline 15 & 1x5.2,5.10D.22 (Jumlah 1×5 II) & 19.125 & 16.495 & 2.630 & 5 & 0.526 \\
\hline 16 & 1x5.2,5.10D.22 (Jumlah 1×5 III) & 26.058 & 16.495 & 9.562 & 5 & 1.912 \\
\hline 17 & $2 \times 3.2,5.100 .22$ (Pola $2 \times 3$ ) & 21.754 & 16.495 & 5.259 & 6 & 0.877 \\
\hline 18 & 3×2.2,5.10D.22 (Pola 3×2) & 18.408 & 16.495 & 1.912 & 6 & 0.319 \\
\hline
\end{tabular}

\section{Perhitungan Rasio Plab/Panalitis}

Plab merupakan besarnya gaya yang dapat ditahan oleh cerucuk berdasarkan uji geser di laboratorium atau bisa disebut sebagai $\Delta \mathrm{P} 1$ cerucuk. Besarnya Plab bergantung pada variasi perlakuan sampel tanah-cerucuk. Sedangkan Panalitis merupakan besarnya gaya geser yang mampu ditahan cerucuk yang didapat dari perhitungan menggunakan rumus NAFVAC DM-7. Nilai rasio Plab dengan Panalitis menunjukkan besarnya peningkatan tahanan geser tanah pada pengujian di Laboratorium akibat adanya variasi perlakuan cerucuk dibandingkan dengan pehitungan teori. Hasil perhitungan Panalitis dan rasio Plab/Panalitis untuk masing-masing perlakuan ditampilkan pada Tabel 6.

\section{ANALISA DATA}

\section{A. Pengaruh Jarak Pemasangan Cerucuk terhadap Pengingkatan Tahanan Geser Tanah}

Jarak pemasangan cerucuk yang digunakan pada penelitian adalah 10 kali diameter (10D) dan 15 kali diameter (15D). Dengan diameter sebesar $2.5 \mathrm{~mm}$ maka jarak 10D sama dengan $25 \mathrm{~mm}$ dan 15D sama dengan $37.5 \mathrm{~mm}$

Hasil dari permodelan persamaan ditunjukkan oleh Gambar 4. Grafik tersebut diperoleh dari rasio Plab S/D $\neq 5$ dengan S/D $=5$, sehingga pada $\mathrm{S} / \mathrm{D}=5$ nilai rasionya 1 . Pola yang ditunjukkan menurun pada nilai rasio spasi dengan diameter (S/D) lebih dari 5. Hal ini disebabkan karena semakin besar spasi atau semakin renggang pemasangan cerucuk, maka cerucuk akan berperilaku sebagai tiang tunggal yang tidak terikat oleh sesamanya. Kondisi ini mengakibatkan semua gaya yang terjadi akan dipikul oleh satu cerucuk itu sendiri, bukan dibagi rata dengan cerucuk yang lain.

\section{B. Pengaruh Diameter Cerucuk terhadap Peningkatan Tahanan Geser Tanah}

Diameter yang digunakan pada penelitian ini adalah diameter $2 \mathrm{~mm}$ dan 2,5 $\mathrm{mm}$ dengan jarak pemasangan 15D dan rasio panjang tancap terhadap diameter adalah 22 .
Tabel 6

Perhitungan Panalitis dan rasionya

\begin{tabular}{|c|l|c|c|c|c|c|c|c|c|c|}
\hline No. & Nama Sampel & Jumlah cerucuk & D & L & I & Cu & qu & qu & f & f \\
\hline & & & cm & cm & cm4 & kg/cm2 & kg/cm2 & TSF & TSF & kg/cm \\
\hline 1 & $1 \times 3.25 .10 D .22$ & 3 & 0.25 & 5.5 & 0.0001917 & 0.0753 & 0.1506 & 0.1541 & 1.5415 & 0.049 \\
\hline 2 & $1 \times 3.2,5.10 D .22$ & 3 & 0.25 & 5.5 & 0.0001917 & 0.0540 & 0.1079 & 0.1104 & 1.10449 & 0.035 \\
\hline 3 & $1 \times 3.2,5.15 D .22$ & 3 & 0.25 & 5.5 & 0.0001917 & 0.0573 & 0.1145 & 0.1172 & 1.17246 & 0.038 \\
\hline 4 & $1 \times 3.2 .15 D .22$ & 3 & 0.2 & 5.5 & 0.0000785 & 0.0540 & 0.1079 & 0.1104 & 1.10449 & 0.035 \\
\hline 5 & $1 \times 3.2 .15 D .22$ & 3 & 0.2 & 5.5 & 0.0000785 & 0.0540 & 0.1079 & 0.1104 & 1.10449 & 0.035 \\
\hline 6 & $1 \times 3.2 .15 D .22$ & 3 & 0.2 & 5.5 & 0.0000785 & 0.0540 & 0.1079 & 0.1104 & 1.10449 & 0.035 \\
\hline 7 & $1 \times 3.2,5.15 D .22$ & 3 & 0.25 & 5.5 & 0.0001917 & 0.0573 & 0.1145 & 0.1172 & 1.17246 & 0.038 \\
\hline 8 & $1 \times 3.25 .10 D .22$ & 3 & 0.25 & 5.5 & 0.0001917 & 0.0753 & 0.1506 & 0.1541 & 1.5415 & 0.049 \\
\hline 9 & $1 \times 3.2,5.10 D .24$ & 3 & 0.25 & 6 & 0.0001917 & 0.0573 & 0.1145 & 0.1172 & 1.17246 & 0.038 \\
\hline 10 & $1 \times 3.2,5.10 D .24$ & 3 & 0.25 & 6 & 0.0001917 & 0.0573 & 0.1145 & 0.1172 & 1.17246 & 0.038 \\
\hline 11 & $1 \times 3.2,5.10 D .28$ & 3 & 0.25 & 7 & 0.0001917 & 0.0573 & 0.1145 & 0.1172 & 1.17246 & 0.038 \\
\hline 12 & $1 \times 2.25 .10 D .22$ & 2 & 0.25 & 5.5 & 0.0001917 & 0.0567 & 0.1134 & 0.1160 & 1.16038 & 0.037 \\
\hline 13 & $1 \times 3.2,5.10 D .22$ & 3 & 0.25 & 5.5 & 0.0001917 & 0.0540 & 0.1079 & 0.1104 & 1.10449 & 0.035 \\
\hline 14 & $1 \times 5.25 .10 D .22$ & 5 & 0.25 & 5.5 & 0.0001917 & 0.0567 & 0.1134 & 0.1160 & 1.16038 & 0.037 \\
\hline 15 & $1 \times 5.2,5.10 D .22$ & 5 & 0.25 & 5.5 & 0.0001917 & 0.0567 & 0.1134 & 0.1160 & 1.16038 & 0.037 \\
\hline 16 & $1 \times 5.25 .10 D .22$ & 5 & 0.25 & 5.5 & 0.0001917 & 0.0567 & 0.1134 & 0.1160 & 1.16038 & 0.037 \\
\hline 17 & $2 \times 3.2,5.10 D .22$ & 6 & 0.25 & 5.5 & 0.0001917 & 0.0567 & 0.1134 & 0.1160 & 1.16038 & 0.037 \\
\hline 18 & $3 \times 2.2,25.10 D .22$ & 6 & 0.25 & 5.5 & 0.0001917 & 0.0567 & 0.1134 & 0.1160 & 1.16038 & 0.037 \\
\hline
\end{tabular}

\begin{tabular}{|c|c|c|c|c|c|c|c|c|c|}
\hline No. & Nama Sampel & $\bar{E}$ & $\bar{T}$ & L/T & $\mathrm{Fm}$ & Mp & Panalitis & $\Delta$ Plab 1 cerucuk & Ratio \\
\hline & & $\mathrm{kg} / \mathrm{cm} 2$ & $\mathrm{~cm}$ & & & $\mathrm{~kg} . \mathrm{cm}$ & $\mathrm{kg}$ & $\mathrm{kg}$ & Plab/Pan \\
\hline 1 & $1 \times 3.2,5.10 \mathrm{D} .22$ & 298406.08 & 4.101 & 1.341 & 1 & 4.960 & 1.209 & 0.2656 & 0.220 \\
\hline 2 & $1 \times 3.2,5.10 \mathrm{D} .22$ & 298406.08 & 4.384 & 1.255 & 1 & 4.960 & 1.131 & 1.9922 & 1.761 \\
\hline 3 & $1 \times 3.2,5.15 \mathrm{D} .22$ & \begin{tabular}{|l|}
298406.08 \\
\end{tabular} & 4.332 & 1.270 & 1 & 4.960 & 1.145 & 1.6734 & 1.461 \\
\hline 4 & $1 \times 3.2 .15 \mathrm{D} .22$ & 298406.08 & 3.667 & 1.500 & 1 & 2.489 & 0.679 & 1.9922 & 2.935 \\
\hline 5 & 1×3.2.15D.22 & 298406.08 & 3.667 & 1.500 & 1 & 2.489 & 0.679 & 1.9922 & 2.935 \\
\hline 6 & $1 \times 3.2 .15 \mathrm{D} .22$ & 298406.08 & 3.667 & 1.500 & 1 & 2.489 & 0.679 & 1.9922 & 2.935 \\
\hline 7 & $1 \times 3.2,5.15 D .22$ & \begin{tabular}{|l|}
298406.08 \\
\end{tabular} & 4.332 & 1.270 & 1 & 4.960 & 1.145 & 2.0719 & 1.809 \\
\hline 8 & $1 \times 3.2,5.10 \mathrm{D} .22$ & 298406.08 & 4.101 & 1.341 & 1 & 4.960 & 1.209 & 0.2656 & 0.220 \\
\hline 9 & $1 \times 3.2,5.10 \mathrm{D} .24$ & 298406.08 & 4.332 & 1.385 & 1 & 4.960 & 1.145 & 2.6297 & 2.296 \\
\hline 10 & $1 \times 3.2,5.10 \mathrm{D} \cdot 24$ & 298406.08 & 4.332 & 1.385 & 1 & 4.960 & 1.145 & 1.8328 & 1.601 \\
\hline 11 & $1 \times 3.2,5.10 \mathrm{D} .28$ & 298406.08 & 4.332 & 1.616 & 1 & 4.960 & 1.145 & 3.2672 & 2.853 \\
\hline 12 & $1 \times 2.2,5.10 D \cdot 22$ & 298406.08 & 4.341 & 1.267 & 1 & 4.960 & 1.143 & 2.5101 & 2.197 \\
\hline 13 & $1 \times 3.2,5.10 \mathrm{D} .22$ & 298406.08 & 4.384 & 1.255 & 1 & 4.960 & 1.131 & 1.9922 & 1.761 \\
\hline 14 & $1 \times 5.2,5.10 \mathrm{D} \cdot 22$ & 298406.08 & 4.341 & 1.267 & 1 & 4.960 & 1.143 & 2.0559 & 1.799 \\
\hline 15 & $1 \times 5.2,5.10 \mathrm{D} .22$ & 298406.08 & 4.341 & 1.267 & 1 & 4.960 & 1.143 & 0.5259 & 0.460 \\
\hline 16 & $1 \times 5.2,5.10 D \cdot 22$ & 298406.08 & 4.341 & 1.267 & 1 & 4.960 & 1.143 & 1.9125 & 1.674 \\
\hline 17 & $2 \times 3.2,5.10 \mathrm{D} .22$ & 298406.08 & 4.341 & 1.267 & 1 & 4.960 & 1.143 & 0.8766 & 0.767 \\
\hline 18 & $3 \times 2.2,5.100 .22$ & \begin{tabular}{|l|}
298406.08 \\
\end{tabular} & 4.341 & 1.267 & 1 & 4.960 & 1.143 & 0.3187 & 0.279 \\
\hline
\end{tabular}

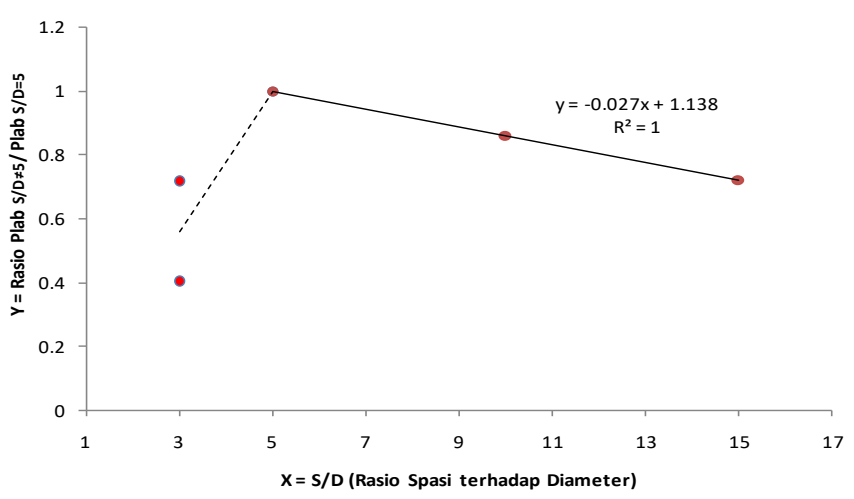

Gambar 4. Perumusan persamaan variasi jarak pemasangan cerucuk

Pembagi masing-masing Plab pada variasi diameter untuk menentukan perumusan persamaan akibat diameter cerucuk adalah Plab pada diameter sama dengan $3 \mathrm{~mm}$. Grafik hasil perhitungan rasio $\mathrm{Plab}_{\mathrm{D} \neq 3 \mathrm{~mm}} / \mathrm{Plab}_{\mathrm{D}=3 \mathrm{~mm}}$ ditampilkan pada Gambar 5. Nilai rasio yang semakin menurun dengan D/T yang semakin kecil menunjukkan bahwa semakin kecil diameter maka kekakuan bahan cerucuk juga akan semakin menurun sehingga gaya geser yang mampu diterima juga semakin kecil. 


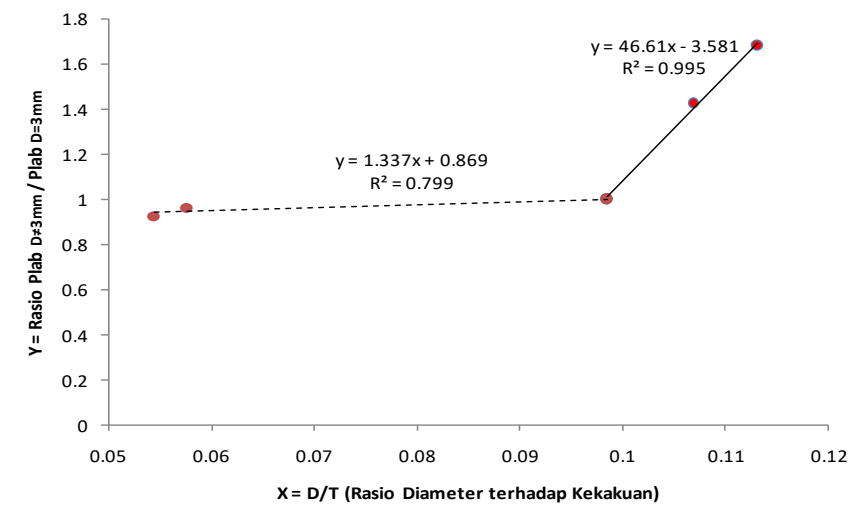

Gambar 5. Perumusan persamaan variasi diameter cerucuk

\section{Pengaruh Panjang Tancap Cerucuk terhadap Peningkatan Tahanan Geser Tanah}

Rasio panjang tancap cerucuk terhadap diameter (L/D) yang digunakan adalah 22, 24, dan 28. Diameter yang digunakan adalah $2.5 \mathrm{~mm}$ maka panjang tancap berturut-turut adalah $55 \mathrm{~mm}, 60 \mathrm{~mm}$, dan $70 \mathrm{~mm}$.

Pada penelitian sebelumnya ditentukan Plab 1 cerucuk pembagi adalah Plab untuk $\mathrm{L} / \mathrm{D}=15$. Grafik yang menunjukkan rasio Plab $_{\mathrm{L} / \mathrm{D} \neq 15} / \mathrm{Plab}_{\mathrm{L} / \mathrm{D}=15}$ ditunjukkan oleh Gambar 6. Grafik mengalami peningkatan seiring dengan meningkatnya nilai L/D. Hal ini menunjukkam bahwa semakin panjang penancapan cerucuk dibawah garis kelongsoran, defleksi yang terjadi semakin kecil sehingga kekuatan cerucuk untuk menerima gaya geser lebih besar.

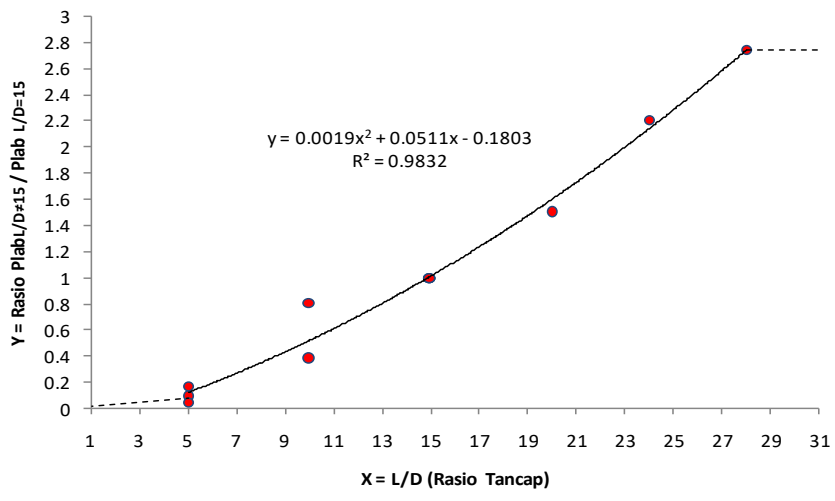

Gambar 6. Perumusan persamaan variasi rasio panjang tancap cerucuk

\section{Pengaruh Jumlah Cerucuk terhadap Peningkatan Tahanan Geser Tanah}

Gambar 7 menunjukkan grafik Rasio Plab untuk jumlah tidak 1 cerucuk dengan Plab pada jumlah sama dengan 1cerucuk. Grafik ini juga bisa disebut sebagai faktor efisiensi tiang. Pola grafik menunjukkan pola menurun. Sehingga dapat disimpulkan bahwa semakin banyak tiang yang dipasang, semakin sedikit gaya yang akan ditahan oleh cerucuk tersebut karena gaya yang terjadi akan dibagi rata dengan banyaknya cerucuk yang dipasang.

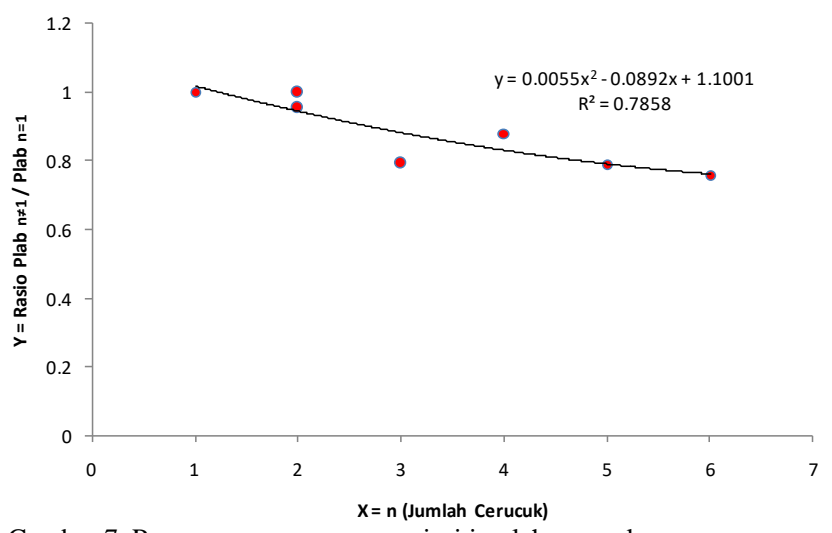

Gambar 7. Perumusan persamaan variasi jumlah cerucuk

\section{E. Pengaruh Pola Pemasangan Cerucuk terhadap Peningkatan Tahanan Geser Tanah}

Perlakuan pola pemasangan pada benda uji ditujukan untuk mengetahui pola yang efektif dalam menerima gaya geser tanah. Variasi pola pemasangan penelitian saat ini masih sama Arah gaya geser diilustrasikan pada Gambar 8 .

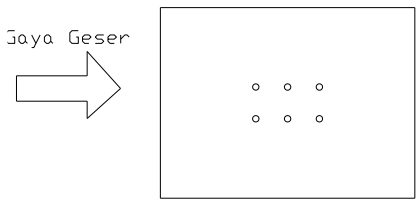

a) Pola $2 \times 3$

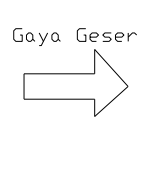

b) Pola $3 \times 2$
Gambar 8. Pola Pemasangan terhadap arah gaya geser

Gambar 9 menunjukkan grafik tegangan regangan pola pemasangan $2 \times 3$ dan $3 \times 2$. Dapat disimpulkan bahwa pada regangan yang sama nilai tegangan geser yang mampu dipikul oleh pola $2 \times 3$ lebih besar dibandingkan dengan pola $3 \times 2$. Hal ini mengindikasikan bahwa penempatan jumlah cerucuk lebih banyak pada arah sejajar gaya geser akan meningkatkan tahanan tanah lebih maksimal disbanding dengan pemasangan arah tegak lurus gaya geser tanah.

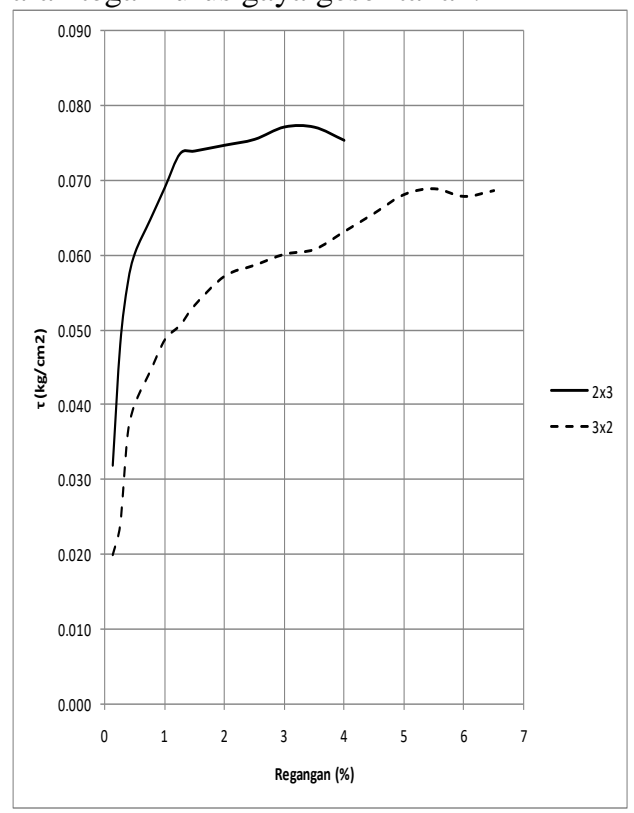

Gambar 9. Grafik tegangan regangan pola pemasangan 


\section{F. Usulan Model Persamaan Tambahan pada Rumus Cerucuk 2015}

Tabel 7.

Usulan Perumusan

\begin{tabular}{|c|c|c|}
\hline Variasi Cerucuk & $\begin{array}{c}\text { Rata-rata } \\
\text { Plab / } \\
\text { Panalitis }\end{array}$ & FORMULA REGRESI \\
\hline Rasio Tancap & \multirow{4}{*}{2.095} & $\begin{array}{l}X t<28, Y t=0.001\left(X^{\wedge} \wedge\right)+0.051(X t)-0.180 \\
X t \geq 28, Y t=2.745\end{array}$ \\
\hline Spasi & & $\begin{array}{l}X s<5, Y s=0.220(X s)-0.101 \\
X s=5, Y s=1 \\
X s>5, Y s=-0.027(X s)+1.138\end{array}$ \\
\hline Jumlah & & $Y n=0.0055\left(X n^{\wedge} 2\right)-0.0892(X n)+1.1001$ \\
\hline Diameter & & $\begin{array}{l}X d<0.098, Y d=1.337(X d)+0.869 \\
X d=0.098, Y d=1 \\
X d>0.098, Y d=46.61(X d)-3.581\end{array}$ \\
\hline
\end{tabular}

Tabel 7 merupakan perumusan faktor koreksi gabungan. Sehingga rumus cerucuk Mochtar (2000) dapat ditulis sebagai:

$$
P \max (1 \text { cerucuk })=\frac{M p_{\max }(1 \text { cerucuk })}{f_{m} \times T} \times F k g
$$

Dimana:

$\mathrm{Fkg}=2.095^{*} \mathrm{Yt}^{*} \mathrm{Yd}^{*} \mathrm{Ys} * \mathrm{Yn}$

Fkg = faktor koreksi gabungan

$\mathrm{P}_{\max 1 \text { cerucuk }}=$ gaya horizontal maksimum yang diterima cerucuk $(\mathrm{kg})$

Mpmax = momen lentur yang bekerja pada cerucuk akibat $\mathrm{P}$ (kg.cm)

$\mathrm{Fm}=$ koefisien momen akibat gaya lateral $\mathrm{P}$ (dari kurva NAVFAC DM-7)

$\mathrm{T}=$ Faktor kekakuan relative $(\mathrm{cm})$ dari kurva NAVFAC DM-7

\section{KESIMPULAN DAN SARAN}

\section{A. Kesimpulan}

1. Uji lentur pada cerucuk menghasilkan nilai modulus elastisitas

2. sebesar $29243.8 \mathrm{~N} / \mathrm{mm}^{2}$ dengan standar deviasi sebesar $11 \%$. Uji sifat fisik dari tanah menunjukkan tanah yang berjenis lempung dengan nilai berat volume $1.345 \mathrm{t} / \mathrm{m}^{3}$ dan kadar air $100 \%$

3. Hasil pengujian geser cerucuk dengan variasi perlakuan spasi mengindikasikan bahwa semakin renggang pemasangan cerucuk, maka semakin kecil pula kemampuan cerucuk untuk menahan gaya geser. Persamaan yang diperoleh $\mathrm{Xs}<5 \mathrm{Ys}=-$ $0.220(\mathrm{Xs}) \quad-0.101, \quad \mathrm{Xs}=5 \quad \mathrm{Ys}=1 \mathrm{Xs}>5, \quad \mathrm{Xs}>5 \quad \mathrm{Ys}=-$ $0.027(\mathrm{Xs})+1,138$.

4. Hasil pengujian geser cerucuk dengan variasi perlakuan diameter cerucuk mengindikasikan bahwa semakin besar rasio diameter dengan kekakuan bahan, maka semakin besar pula kemampuan cerucuk untuk menahan gaya geser. Persamaan yang diperoleh $\mathrm{Xd}<0.098 \mathrm{Yd}=1.337(\mathrm{Xd})+$ 0.869, Xd=0.098 Yd=1, Xd>0.098 Yd=46.616(Xd)-3.581.

5. Hasil pengujian geser cerucuk dengan variasi perlakuan rasio tancap cerucuk mengindikasikan bahwa semakin besar rasio tancap terhadap diameter, maka semakin besar pula kemampuan cerucuk untuk menahan gaya geser. Persamaan yang diperoleh $\mathrm{Xt}<28, \mathrm{Yt}=0.001\left(\mathrm{Xt}^{2}\right)+0.051(\mathrm{Xt})-0.180$, dan untuk $\mathrm{Xt} \geq 28, \mathrm{Yt}=2.745$
6. Hasil pengujian geser cerucuk dengan variasi perlakuan jumlah cerucuk cerucuk mengindikasikan bahwa semakin banyak cerucuk yang dipasang, maka semakin kuat perkuatan pada lereng tersebut. Persamaan yang diperoleh $\mathrm{Yn}=$ $0.0055(\mathrm{Xn})^{2}-0.0892(\mathrm{Xn})+1.1001$

7. Pola pemasangan yang lebih efisien adalah jumlah cerucuk arah sejajar gaya geser. Karena pada pola tersebut, tahanan tanah yang dierikan oleh cerucuk akan lebih maksimal dibandingkan dengan pola tegak lurus terhadap gaya geser.

8. Koefisien pengali yang dihasilkan adalah 2.095.

\section{B. Saran}

Setelah dilakukan analisis penelitian, penulis memberikan saran yaitu:

1. Perlu diadakan penelitian lanjut dengan jumlah benda uji yang lebih banyak pada setiap variasi perlakuan agar bisa lebih valid dalam perumusan persamaan statistic.

2. Perbandingan perumusan perlu diperluas dengan metode yang lebih beragam, untuk mengetahui tingkat ketidaksamaan hasil perhitungan.

3. Perlu dilakukan perbaikan dalam analisa perumusan menggunakan program bantu yang lebih beragam. Agar antara hasil penelitian di Laboratorium bisa mendekati hasil perumusan menggunakan program bantu.

\section{DAFTAR PUSTAKA}

[1] Firat, Seyhan. 2009. Review Stability Analysis of Pile-Slope System. Turkey: Sakarya University

[2] Mochtar, I. B dan Arya I.W., 2002, Pengaruh penambahan cerucuk terhadap peningkatan kuat geser tanah lunak pada permodelan di Laboratorium, Tesis Bidang Geoteknik, Program Studi teknik Sipil, Program Pascasarjana ITS Surabaya

[3] NAVFAC DM-7, 1971, Design Manual, Soil Mechanic, Foundation and Earth Strucutures, Depth. Of the Naval Facilities Engineering Command, Virginia, USA

[4] Rusdiansyah. 2015. Mekanisme Peningkatan Tahanan Geser Tanah Lunak Akibat Adanya Cerucuk Berdasarkan Permodelan Empiris di Laboratorium. Jurusan Teknik Sipil ITS 